\title{
Mega-Retail-Led Regeneration and Housing Price
}

\author{
How Does Westfield London Shopping Centre Affect Gentrification \\ of Deprived Neighbourhoods in White City, London?
}

Jae Kwang Lee

Abstract: With the ongoing shift in the dynamics of retail development toward in$\overline{\text { ner-city sites, mega-retail-led regeneration }}$ schemes have emerged as an important strategy for place marketing in the entrepreneurial city of London. While a number of studies have attempted to examine the effects of these schemes, the focus of previous studies has been limited to their wider economic and environmental effects. However, few studies have empirically investigated their impact on surrounding neighborhoods, particularly deprived neighborhoods. This paper investigates the effects of the Westfield London Shopping Centre on changes in housing price levels in the surrounding neighborhood of White City/Shepherd's Bush, in order to determine whether $\overline{\text { mega-retail-led regeneration schemes are a key }}$ determinant in the process of gentrification. A difference-in-differences analysis was used to assess differentials in the change rates of housing prices between control and treatment groups following the development of Westfield London. It was found that Westfield London development caused an increase in the change rate of housing prices of the treatment group relative to that of the control group. These findings indicate that mega-retail-led regeneration schemes may be a main cause of the pricing out of neighborhood residents who cannot afford the resulting increased rents and for altering the characteristics of neighborhoods and their social networks.

\section{Introduction}

Since the Revised Planning Policy Guidance Note 6 (PPG6) was published, the dynamics of large-scale retail development in the United Kingdom have shifted from the construction of out-of-town regional shopping centers toward the exploration of the potential of innercity sites (Jackson, Watkins 20 I I Lowe 2005a). With the change in UK urban governance to- ward urban entrepreneurialism, the potential for retail development in inner cities has been incorporated with urban regeneration schemes implemented for the place marketing of entrepreneurial cities. As geared toward regeneration schemes, retail development that used to take place in the suburbs has been transformed into mega, post-modern, iconic retail development in inner cities, creating a new form of regeneration strategy called "mega-retail-led regeneration" (Tallon 2008, 20 I0). In the entrepreneurial era of inter-urban competition, mega-retail-led regeneration schemes have become an important regeneration strategy for policy-makers and an important development strategy for retailers (Lowe 2005b; Guy 2007).

With the emergence of mega-retail-led regeneration schemes, a number of studies have been undertaken to examine their effects, focusing on their wider economic impact as well as their contribution to job creation (Bromley et al. 2004; Cummins et al. 2005; Lowe 2000, $2005 \mathrm{~b}$; Thomas, Bromley 2002; Robertson, Fennell 2007). Lowe (2005a) reported that the West Quay shopping center in Southampton had a positive impact on boosting local employment as well as improving the image of Southampton as a top shopping location, while Crosby et al. (2006) stated that the Oracle shopping center in Reading had little impact on the local economy. There have been, however, few academic efforts to examine the way megaretail-led regeneration schemes impact surrounding neighborhoods, in comparison to their wider economic impact. Indeed, Dixon $(2005)$ pointed out that it was necessary to look at how large-scale retail development in inner cities would affect the provision of local services and the benefits to the neighborhood.

The emergence of mega-retail-led regeneration schemes has brought a new aspect to the scholarly debate over the justification of retail development projects in inner cities. In this regard, the ways in which retail projects affect their surrounding neighborhoods has become an important issue in delivering mega-retailled regeneration, in addition to the existing
Jae Kwang Lee is a PhD student in Planning Studies at the Bartlett School of Planning, University College London where his research focuses on the synergistic relationship between transport improvement policy and energy efficiency policy. He has worked in China, Japan, and UK on research projects in housing, transportation, and sustainable development. 

tional high street retail, because they are significantly involved in the process of urban renewal and gentrification (Smith 2002). In particular, the causal relationship between mega-retailled regeneration and the gentrification or urban renewal of surrounding neighborhoods has been overlooked in the existing literature. It is important to investigate this relationship because only empirical analysis on a neighborhood scale can provide us with reliable evidence as to whether or not inner-city mega-retail development is a main cause of the gentrification of deprived areas. This paper therefore seeks to investigate the impact of inner-city mega-retail development on the changes in housing price levels of surrounding neighborhoods in order to examine whether mega-retail-led regeneration schemes are a key determinant in the process of neighborhood gentrification.

As Smith (1996) and Hackworth and Smith (200I) stated, the process of gentrification can be understood by looking at capital together with the property market: housing price levels are used as a proxy for the assessment of the rent/price gap that causes communities to find it difficult to stay in their neighborhoods. This paper's hypothesis is that mega-retail-led regeneration schemes lead to an increase in the housing price levels of surrounding neighborhoods, giving rise to their gentrification. Specifically, following the intervention of mega-retail-led regeneration schemes, housing price levels near the development sites increase more than do price levels in other areas. In order to prove this hypothesis, a difference-in-differences analysis was used to measure the treatment effects of Westfield London, a mega-scale shopping center in a deprived area of London, on the changes in housing price levels of the surrounding neighborhood. This was accomplished through the assessment of relative shifts in the change rates of housing prices before and after Westfield London was built.

It is not the intention of this paper to isolate the price effects of inner-city mega-retail development. Rather, its focus is on the impact on the neighborhoods that mega-retailled regeneration schemes have generated in surrounding neighborhoods. This exploration of whether or not mega-retail-led regeneration schemes lead to gentrification could be of importance to policy-makers, providing them with useful information to take into consideration during the development of mega-retailled regeneration.

\section{Theoretical Perspective}

During the $\mathrm{I} 980 \mathrm{~s}$ and $\mathrm{I} 99 \mathrm{os}$, UK retail planning policies dramatically shifted, moving from loose to tight in terms of the location of retail development. In the 1980 s, with liberalized retail planning policies in place, a number of largescale retail developments were established in the suburbs by private developers at the expense of traditional high street retail in inner cities, famously described as the third wave of "retail decentralization" (DOE r 993; Guy r 994; Schiller I 986 ; Wrigley, Lowe 2002). In the I99os, retail planning regulations were tightened in order to control out-of-town retail development. Together with PPG6 and Planning Policy Guidance Note ı 3: Transport (PPG 1 3), a "sequential test" was implemented, requiring all proposed out-of-town retail development to prove the existence of a "need" for the retail space (Adlard $200 \mathrm{I})$. As a result of a series of regulatory restrictions, most of the potential out-of-town shopping centers in the pipeline were not put into practical construction (OXIRM I987).

Those retail planning regulations have caused significant changes in the nature of large-scale retail development as well as its location (ODPM 2005). A range of new retail development formats have emerged in different locations as a substitute for out-of-town retail development, adapting to the retail environment within which the regulation policies were interpreted. For example, large-scale shopping centers have emerged in district sites, and retail parks have been implemented in suburbs by circumventing the regulations (Guy 2002; Thomas, Bromley, Tallon 2006). The most significant change that the regulatory tightening brought about regarding the nature of retail development was the rise in mega-retail development incorporated with urban regeneration plans, the so-called mega-retail-led regeneration schemes (Guy 2008; Lowe 2000, 2005a; Talon 2008). These have quite different features from the large-store-based redevelopments that were once implemented in the UK to revitalize declining retail centers in terms of the rationale behind incorporating retail development into regeneration or redevelopment schemes.

Large-store-based redevelopment has been supported by a strong social inclusion rationale in which retailers or retail developers arrange for the local community (Wrigley et al. 2002). Due to progressively tightening regulations, in mega-retail-led regeneration schemes, the dynamics of retail development have shifted from out-of-town regional centers toward a search 
for retail development opportunities within citycenter sites (Guy, Bennison 2002, 2007). The other underlying force behind the rise of megaretail-led regeneration schemes has been the shift in the governance of cities to urban entrepreneurism, which focuses on cities' competitiveness. With the intensification of globalization, cities have been put in a situation in which they have to attempt to ensure their competitive advantage in place competition (Short, Kim r 999; Hall 2006). In the age of inter-urban competition, global cities have adopted entrepreneurial modes of urban governance and have chosen to use place marketing or city branding as important strategies for securing a competitive advantage (Griffiths r998; Harvey r989). In this context, mega-retail-led regeneration schemes have emerged as a place marketing strategy for entrepreneurial cities. The emergence of mega-retail-led regeneration has been prominent in the UK, along with the particular context of retail planning policies that has given rise to the shift in retail development to inner cities. The government's need for an iconic project that can give it a new urban image has fitted in with retailers' exploration of the potential for inner-city retail development, creating a particular link between urban regeneration and retail development (Lowe 2005a; Talon 2008).

Mega-retail developments in mega-retail-led regeneration schemes have taken the form of prestige developments, which are different from the large-scale retail developments that used to be built in the suburbs. Apart from the typical characteristics of retail development, which normally considers the product layout and the flow of customers, these developments are characterized as mega-scale, high-profile, and selfcontained (Loftman, Nevin i 995; Smyth r 994). In the process of place marketing, prestige development projects have been utilized as essential tools by regeneration agencies. The format of prestige developments has been central to regeneration schemes because the way in which prestige projects promote iconic flagship developments has fitted in well with the aims of place marketing (Loftman, Nevin r 994; Hall 2oo6). As employed in mega-retail-led regeneration for city branding, mega-retail developments have taken on the format of prestige developments in order to achieve the physical transformation of deprived areas of inner cities.

Post-modern style mega-retail developments in inner cities have created new urban images and have contributed to attracting inward investment and tourists to their cities; however, they have also brought about a number of issues and controversies regarding their surrounding neighborhoods. Tallon (2008, 20го) highlighted the four major issues raised by retail-based redevelopment projects: involvement of local communities, exclusion, privatization of central city space, and gentrification. Although not all of these issues are necessarily related to mega-retail-led regeneration schemes, the issue of gentrification is considered to be particularly important in inner-city mega-retail development because its large size and unique features may intensify the process of social displacement by boosting housing prices to a level that poor and working class in deprived areas cannot afford (Phillips 2002).

Housing price and rent levels, which are determined by the interaction of demand for and supply of housing, are central to the mechanism of the gentrification process because they provide residents with the rationale behind the displacement of social class (Smith r 996). In a wider sense, demand for housings in inner cities has been produced by the growth of the service economy and by lifestyle changes (Florida 2002; Tallon, Bromley 2004). The supply of housing has been driven up by developers, landlords, and mortgage lenders, who realized the gap between current rents and capitalized rents (Smith 2000). A more specific factor determining housing prices and rent levels in the neighbourhoods surrounding mega-retail-led regeneration schemes is their development outcome because the extent of demand for and supply of housing in surrounding neighbourhoods is contingent upon what that development bring: improved access to retail services, upgrade of architecture and urban design, improvements in the image of towns/cities, and improvements in the quality of public services. Given that the resulting inflated housing prices and rent levels are the underlying driver behind the pricing out of residents in deprived areas, the outcome of mega-retail developments can, in a sense, be regarded as potential channels through which that development impacts the gentrification process.

\section{Westfield London Retail Development}

Westfield London is a shopping center that was developed as part of a regeneration scheme in the neighborhood of White City and Shepherd's Bush in the London Borough of Hammersmith and Fulham (LBHF 20 I Ib). That neighborhood, previously known as a deprived area, is characterized by a significantly high proportion of private rented accommodations, accounting for 
Fig. I: Location of Westfield London.

(Source: Created by the author

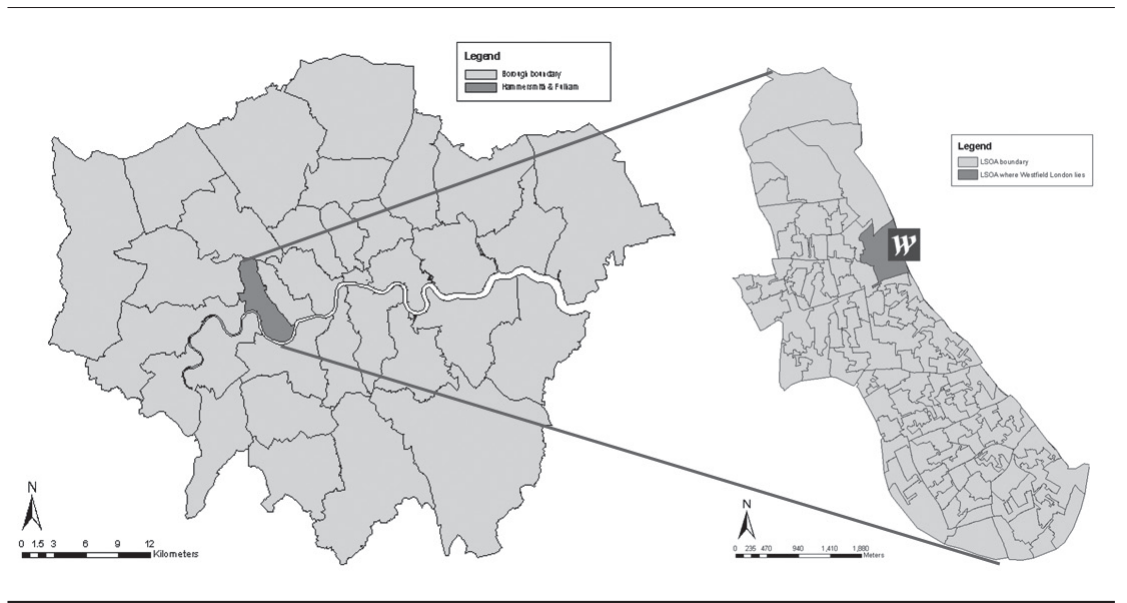

over $30 \%$ of total housing stock in the borough (LBHF 2012 $)^{1}$. Westfield London is the fifth largest shopping center in the UK in terms of retail space, covering r.6 million square feet ${ }^{2}$. It opened its doors on 30 October 2008 and has since drawn attention from a large number of customers. Initially, it was anticipated that approximately 20 million people would visit Westfield London in its first year of trading, but this expectation was exceeded, with 23 million people visiting the center. The opening of Westfield London created around 8,ooo jobs and the physical environment of the surrounding neighborhood was considerably improved (Westfield London 20I0). The center hosts several "flagship" stores and incorporates over 270 other retail outlets, together with "The Village", which contains high-end luxury retailers.

The most noticeable feature of Westfield London development is that a planning obligation, Section ro6 of the r 990 Planning Act, was implemented by the Hammersmith and Fulham Council in order to bring significant benefits to local communities. With a series of agreements between developers and the council, a range of planning components contributing to the local economy and public services were incorporated into the scheme, such as the provision of affordable housing and a public library, employment and training initiatives ${ }^{3}$, as well as numerous transport improvements. In particular, the way in which the retail-regeneration development scheme was integrated with substantial transport improvement is noteworthy. The development scheme included the design of a public transport interchange with new rail, underground, and bus stations connecting directly to the center (LBHF 2000, 2002, 20IIa; TFL 2007). This transportation integration is considered a potential channel through which neigh- borhood effects generated by Westfield London can operate, and is the most important rationale for choosing Westfield London as a case study for this paper.

The initial plan for Westfield London was developed by a consortium in which Multiplex UK, a UK division of the Australian Multiplex Group, was involved. In 2005, the shares held by Multiplex UK were acquired by the Westfield Group, an Australian-based retail company that entered the UK in 2000 . As a result of the take-over, $50 \%$ of the shopping center became owned by the property development company Hammerson plc and 50\% by Westfield (Westfield Group 2oo5). Westfield then took the lead in the development process, and its construction arm, Westfield Construction, began to be involved in the building process. Westfield is one of the most successful global retail property companies, operating a portfolio of 55 centers in the US and 56 centers in Australia and New Zealand, and is valued at US $\$ 5$ r. 3 billion. In the UK, the company first opened Westfield Derby in the East Midlands in October 2007 and currently operates ten regional shopping centers: eight in England and two in Northern Ireland (Westfield Group 20го).

\section{Methodology and Data}

In this study, a difference-in-differences analysis was adopted to examine the neighborhood impact of inner-city mega-retail-led regeneration on changes in housing price levels of the surrounding neighborhood, in this case, White City/Shepherd's Bush in London. Differencein-differences is a well-known method for estimating the treatment effects of interventions. It isolates the treatment effects through the use 


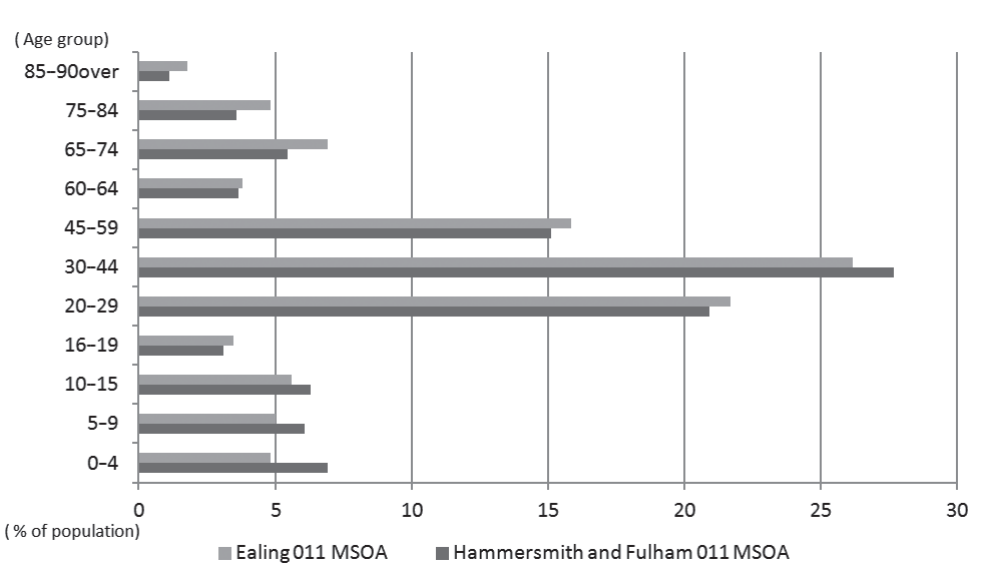

of a control group to "difference out" other irrelevant factors. One of the important tasks in any difference-in-differences analysis is defining treatment and control areas/groups, because the robustness of the analysis relies on the proper selection of those groups (Wooldridge 2008 ). In this paper, the treatment and control areas/groups were carefully selected because Westfield London is located in a dense city-center, so it could be difficult to determine the exact scope of its neighborhood impact, especially because related findings were not available in the literature. As an alternative plan, the 5, ooo-meter distance, used as the scope of neighborhood impact of a stadium in Tu's 2005 study, was adjusted to the present analysis, considering that Westfield London is smaller than the stadium. Accordingly, the treatment area of this analysis was defined as the area within I, ooo meters of Westfield London. The control area was defined as a corresponding area that has a similar demographic structure to the treatment area and that is located outside of the I,ooo-meter radius around Westfield London. Figure 2 shows the demographic structures of the two areas in $200 \mathrm{I}$, indicating that they are comparable with each other in terms of demographic features. Given that the outcome of neighborhood development projects is generally enjoyed by residents within walking distance in urban spaces (Ahlfeldt, Maennig 2009), a distance threshold of $\mathrm{I}, \mathrm{ooo}$ meters is reasonable; in this case, a distance threshold of 500 meters was also used in order to verify the robustness of the differencein-differences analysis.

The dataset used in this study contains the change rate of housing prices before and after the inauguration of Westfield London, calculated from transactions of individual house in the treatment and control areas during the years 2000-20II. Observation of individual house transactions focuses on identical houses because the use of identical houses made it possible to not have to control the characteristics of houses in the analysis. Considering the purpose of this study, focusing on identical houses can be an efficient way of looking at the changes in housing price levels. Accordingly, the basic units of observation are transactions of identical houses in the treatment and control areas that were registered in the Land Registry in the years 2000, 2005, and 20 II. The Land Registry is an executive government agency that carries out the role of registrar referred to in the Land Registration Act 2002 and has an unquestioned reputation; hence, these data are regarded as reliable (Land Registry 2ог гa). Transaction information collection was carried out for three time points, 2000, 2005, and $20 \mathrm{II}$, in order to produce the rates of change in the prices of identical houses for the periods $2000-2005$ and 2005-20II, before and after the intervention of Westfield London.

The analysis focuses on the inauguration date, when Westfield London development was initiated, rather than the completion date because it is implicitly assumed that the housing market exhibits information efficiency in which housing prices capitalize on any expected net externality effects in advance of actual project completion. The use of the inauguration date has been adopted in many previous studies (Colwell, Dehring 2000; Dehring et al. 2007).

The rate of population change and the rate of change in General Certificate of Secondary Education (GCSE) scores are used as control variables because they are considered major factors affecting change in housing prices Hoesli, MacGregor 2000). Considering that longitudinal data for the years $200 \mathrm{I}, 2005$, and 2009 at
Fig. 2: Demographic structures of the treatment and control areas $200 \mathrm{I}$. (Source: Neighborhood Statistics, $200 \mathrm{I})$ 

were not available, the use of these two variables is reasonable, although there are other neighborhood characteristics that may influence changes in housing prices.

A simple specification of difference-in-differences analysis is used in this study (Ahlfeldt, Maennig 2009; Redding, Sturm 2008). In the specification, the analysis regresses the rates of change in housing prices $\left(H_{i t}\right)$ on a time dummy $\left(T_{t}\right)$, taking the value I if they are prior to the intervention; on a location dummy $\left(X_{i}\right)$, taking the value $I$ if they are located within I ooom of Westfield London; and on an interaction term between the time dummy and the location dummy $\left(T_{t} \cdot X_{i}\right)$. The baseline econometric equation is as follows:

$$
H_{i t}=\beta_{0}+\delta_{0} T_{t}+\beta_{1} X_{i}+\delta_{1} T_{t} \cdot X_{i}+\varepsilon_{i t}
$$

The intercept $\beta_{0}$ captures the average rates of change in the housing prices of the control group in the pre-treatment period. The parameter $\delta_{0}$ on the time dummy $\left(T_{t}\right)$ captures the change rates of housing values in the control group in the post-treatment period. A negative and statistically significant coefficient for $\delta_{0}$ would indicate that the growth rates of housing prices in the control group declined during the period 2005-20II. The parameter $\beta_{1}$ on the location dummy $\left(X_{i}\right)$ measures the change rates of housing prices in the treatment group prior to the existence of Westfield London. The parameter $\delta_{1}$ on the interaction term between the time dummy and the location dummy captures the treatment effect of Westfield London development on the relative performance of housing prices in the treatment and control groups in the post-treatment period. A positive and statis-

tically significant value for $\delta_{1}$ would indicate a positive impact on the rates of change of housing prices in the treatment group after the inauguration of Westfield London development.

\section{Empirical Results}

The baseline specification of the difference-indifferences analysis compares the change rates of housing prices in the treatment group with those of the control group before and after the inauguration of Westfield London development, controlling for changes in both population and education. The location of the treatment and control areas are shown in Figure 3.

The coefficient $\beta_{1}$ on the location dummy $\left(X_{i}\right)$ is negative but not statistically significant, pointing to no systematic differences in the rates of change of housing prices between the treatment group and the control group in the pre-treatment period. This implies that the two groups had experienced similar changes in housing prices before Westfield London development started. The further implication is that they are comparable with each other in terms of changes in housing price levels, and suggests that the choice of the treatment and control groups was proper and valid.

The coefficient $\delta_{1}$ on the interaction term $\left(T_{t} \cdot X_{i}\right)$ is positive and statistically significant, consistent with the hypothesis. The coefficient $\delta_{1}$ captures the treatment effect of Westfield London development on the shift in the change rates of housing prices of the treatment group relative to that of the control group in the postintervention period. The significantly positive coefficient $\delta_{1}$ indicates that Westfield London

Fig. 3: Locations of the treatment and control groups. (Source: Created by the author, based on Bing map)

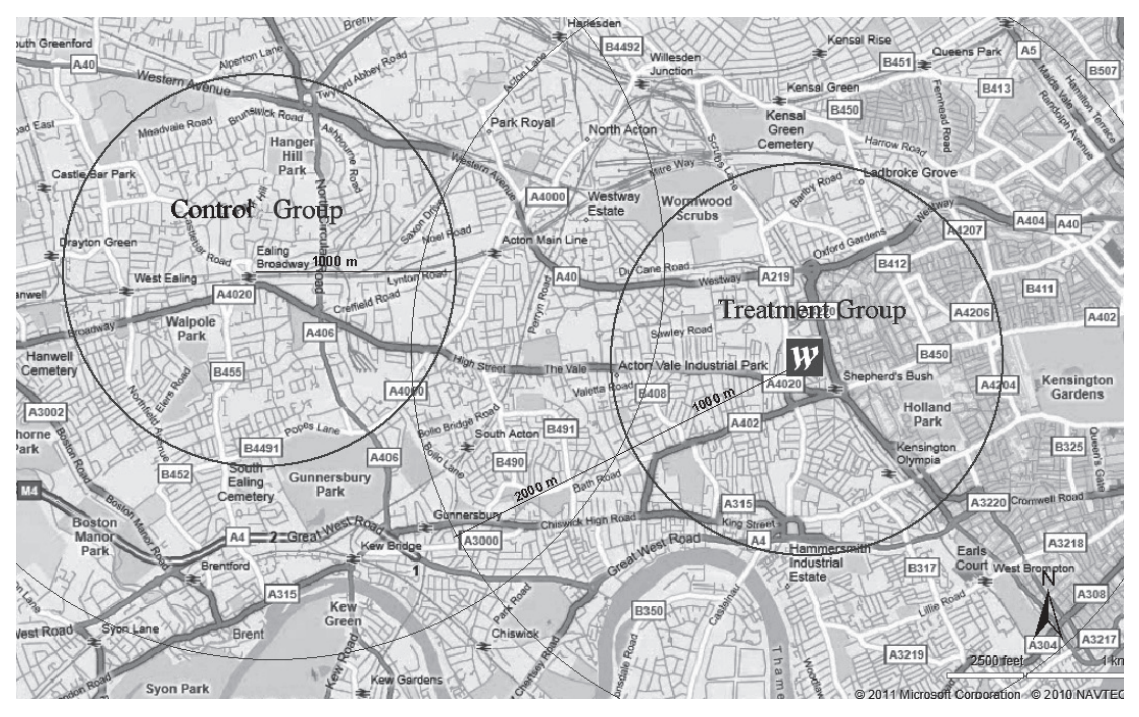


development caused a relative increase in the rate of change of housing prices of the treatment group. This increase resulted from an increased demand for housings in the surrounding neighbourhoods as numerous planning components of Westfield London development improved that neighbourhood's living environment. In particular, substantial improvement in the transport network of White City/Shepherd's Bush seems to be a major contributor to the rise in housing price levels. This implies that residents in the treatment group might be priced out of the neighbourhood and replaced by new influxes of professionals who can afford the inflated rents/prices. In addition, given that the proportion of private rented accommodation in White City/Shepherd's Bush is far higher than that of London, the extent to which the inflated rents/prices put pressure on residents in the deprived areas around Westfield London seems considerable, thereby leading to social displacement (LBHF 20 I2). These findings point to the idea that Westfield London development might have resulted in a change in the characteristics and social network of its neighbourhood.

Table I presents the parametric results of the difference-in-differences analysis. In column (I), equation (I), the baseline econometric specification is estimated. The change rates of housing prices between 2000 and 20 II were regressed on the time dummy $\left(\boldsymbol{T}_{t}\right)$, the location dummy $\left(X_{i}\right)$, and the time $\mathrm{x}$ location interaction $\left(T_{t} \cdot X_{i}\right)$. This estimation was repeated with the control variables, and the estimated results are presented in columns (2) and (3). In column (I), the constant accounts for the average rates of change of housing prices in the control group in the period 2000-2005. This period was accompanied by an upturn cycle of UK property markets (Barras 2009). The favorable circumstances of UK property markets give an account of the significantly positive coefficient $\beta_{0}$. The coefficient $\delta_{0}$ on the time dummy $\left(T_{t}\right)$ is slightly negative and statistically significant, indicating that the change rates of housing prices of the control group had dropped slightly in the post-treatment period. This estimate is consistent with the fact that the growth rates of housing prices in London had decreased during the same period due to the recent financial crisis (Land Registry 20 I Ib).

Inner-city areas comprise a range of built environments that differ in size and function, such as roads, railways, buildings, and parks. As some of the built environments in White City/Shepherd's Bush could be sensitive to the neighborhood effects of Westfield London development, it is possible that those built environments may be disturbed or interrupted. Thus, an additional test was required to check the robustness of the analysis and to look at how the neighborhood effects of Westfield London vary with the distance away from it.

In column (4) of Table I, the baseline estimation was repeated again with a different distance threshold in order to check the robustness of the analysis. Instead of a distance threshold of rooo meters, this estimation used a distance threshold of 500 meters. Other conditions in the estimation were the same as the baseline
Tab. I: Estimated Results of the Difference-in-Differences Analysis.

\begin{tabular}{|c|c|c|c|c|}
\hline & $\begin{array}{l}(1) \\
\text { Housing Price Growth } \\
(\text { Threshold }=1000 \mathrm{~m}) \\
(\mathrm{N}=316)\end{array}$ & $\begin{array}{l}(2) \\
\text { Housing Price Growth } \\
(\text { Threshold }=1000 \mathrm{~m}) \\
(\mathrm{N}=316)\end{array}$ & $\begin{array}{l}(3) \\
\text { Housing Price Growth } \\
(\text { Threshold }=1000 \mathrm{~m}) \\
(\mathrm{N}=316)\end{array}$ & $\begin{array}{l}(4) \\
\text { Housing Price Growth } \\
(\text { Threshold }=500 \mathrm{~m}) \\
(\mathrm{N}=226)\end{array}$ \\
\hline Constant & $\begin{array}{c}0.41428^{* * * *} \\
(0.02680)\end{array}$ & $\begin{array}{l}0.41184^{\text {**** }} \\
(0.02684)\end{array}$ & $\begin{array}{c}0.40029^{* * *} \\
(0.02780)\end{array}$ & $\begin{array}{l}0.40164^{\text {**** }} \\
(0.02684)\end{array}$ \\
\hline Ypost $\left(T_{t}\right)$ & $\begin{array}{c}-0.11742^{\text {*** }} \\
(0.03790)\end{array}$ & $\begin{array}{c}-0.11769^{* *} \\
(0.03786)\end{array}$ & $\begin{array}{c}-0.11845^{\text {*** }} \\
(0.03778)\end{array}$ & $\begin{array}{c}-0.11836^{* *} \\
(0.03588)\end{array}$ \\
\hline Nearwsf $\left(X_{i}\right)$ & $\begin{array}{r}-0.00839 \\
(0.03697)\end{array}$ & $\begin{array}{r}-0.00122 \\
(0.03736)\end{array}$ & $\begin{array}{r}-0.00202 \\
(0.03728)\end{array}$ & $\begin{array}{r}-0.00571 \\
(0.04413)\end{array}$ \\
\hline Ypost $\cdot \operatorname{Nearwsf}\left(T_{t} \cdot X_{i}\right)$ & $\begin{array}{l}0.32123^{\text {*** }} \\
(0.05229)\end{array}$ & $\begin{array}{l}0.32031^{\text {***** }} \\
(0.05224)\end{array}$ & $\begin{array}{l}0.32000^{\text {**** }} \\
(0.05213)\end{array}$ & $\begin{array}{c}0.32796^{\text {**** }} \\
(0.06198)\end{array}$ \\
\hline Controls & No & Population & Population, Education & Population, Education \\
\hline R-squared & 0.1948 & 0.1990 & 0.2051 & 0.2162 \\
\hline $\begin{array}{l}\text { Adjusted } \\
\text { R-squared }\end{array}$ & 0.1871 & 0.1887 & 0.1923 & 0.1984 \\
\hline
\end{tabular}

Note: Ypost is a dummy that is set at 0 except for the years 2005-2011, when the development of Westfield London began to affect surrounding areas, in which case it takes the value 1 . Nearwsf is a dummy that takes the value of 1 if a house lies within 1000 meters of Westfield London and 0 otherwise. ${ }^{*}$ denotes significance at the $10 \%$ level; ${ }^{* *}$ denotes significance at the $5 \%$ level; ${ }^{* * *}$ denotes significance at the $1 \%$ level. 
Fig.4: Indices of the growth rates of housing prices.

(Source: Created by the author based on house transactions collected from the Land Registry

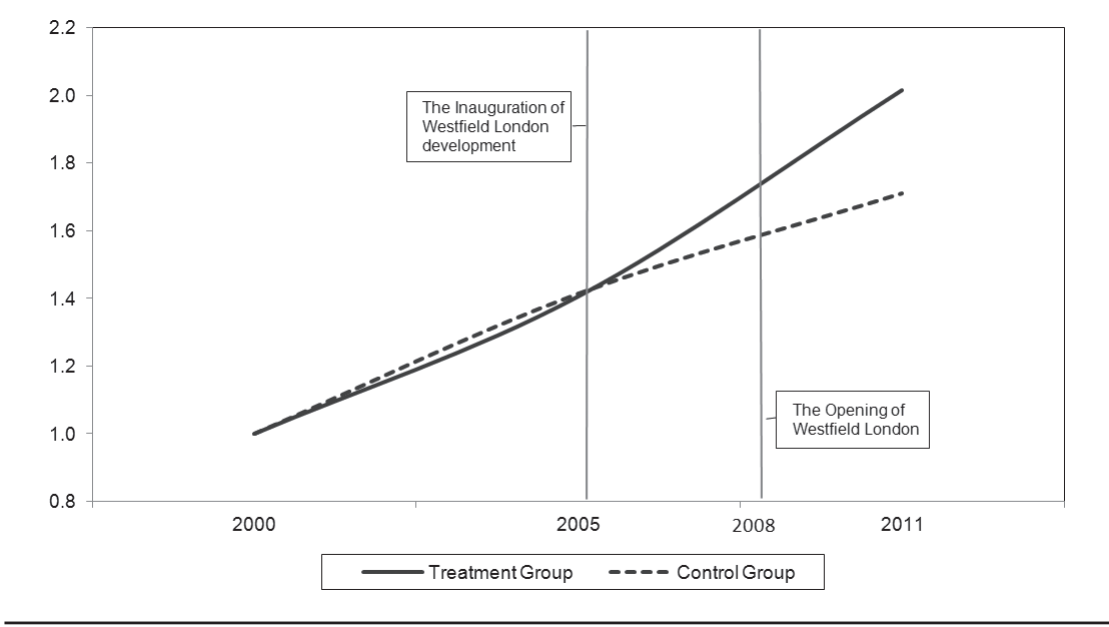

specification. The estimated coefficients on the constant, the location dummy $\left(X_{i}\right)$, and the time dummy $\left(\boldsymbol{T}_{t}\right)$ are similar to those in column (3). The estimated coefficient on the interaction term $\left(T_{t} \cdot X_{i}\right)$ in column (4) is as positive and statistically significant as the baseline estimation, except that the coefficient $\delta_{1}$ is slightly higher. In a narrow sense, this can be interpreted as indicating that the treatment effects of Westfield London are stronger within 500 meters of Westfield London. In a broad sense, it indicates that the treatment effects of Westfield London continue to be retained within the 5oo-meter distance. These interpretations verify the robustness of the analysis.

Figure 4 presents the estimated results of the baseline specification, graphing the estimates of housing prices during the periods of the treatment and the control groups. For each group, the change rates of housing prices were calculated using house transactions and were then expressed as an index relative to its 2000 value, so that the index takes on the value that it had in 2ooo. The solid line represents the change rate of housing prices of the treatment group and the dotted line represents that of the control group. The two vertical lines respectively indicate the year 2005, when Westfield London development was initiated, and the year 2008 , when Westfield London opened. Prior to the first vertical line, the change rate of housing prices of the treatment group was slightly lower than that of the control group. Given that these two groups are comparable with each other in terms of location features, the difference in the change rates of housing prices indicate the treatment effects from the intervention of Westfield London development. In the pre-intervention period, the change rate of housing prices of the treatment group was slightly inferior to that of the control group. This lower change rate of treatment group housing prices is consistent with what was experienced before 2005. During the pre-intervention period, due to the land assembly and site clearance for Westfield London development, the neighborhood of the treatment group suffered from several nuisances, such as noise, dust, and traffic congestion. It seems that those inconveniences were reflected in the change rate of housing prices of the treatment group.

As Figure 4 shows, the change rate of both groups' housing prices started to shift sharply after the inauguration of Westfield London development. From this point onward, the treatment group, which was located in the deprived area around Westfield London, experienced a higher rate of change in housing prices than the control group. This implies that the mega-retail-led regeneration scheme of Westfield London brought about inflated rents/prices that may ultimately lead to the pricing-out of residents of the surrounding neighborhood.

\section{Conclusion}

This paper investigated the effects of the development of Westfield London, a mega-retail-led regeneration project, on the changes in housing price levels of the surrounding neighborhood in order to determine whether it is a key determinant in the process of gentrification. The treatment effects that the intervention of Westfield London have had on the change rate of housing prices were estimated through a difference-in-differences analysis. It was found that the change rates of housing prices of the treat- 
ment group increased far more than those of the control group following the intervention of Westfield London development, indicating that housing price levels have increased in the deprived area surrounding the shopping center. The paper therefore, concludes that mega-retail-led regeneration schemes may be a main cause for pricing out the residents of neighborhoods surrounding these urban shopping centers.

The findings of this analysis provide two important implications for policy-makers and urban planners. As the economic effects of megaretail-led regeneration schemes have arguably not been definite in terms of actual beneficiaries, it seems that the dimension of their neighborhood effect needs to be emphasized more in practice. Considering that mega-retail-led regeneration schemes may price out neighborhood residents who cannot afford inflated rents, such schemes' negative effects on surrounding neighborhoods need to be regarded as an important factor in the implementation process, just as other economic effects are. Ignoring them could result in serious errors in delivering successful outcomes of mega-retail-led regeneration. A systematic effort is needed in planning policies in order to understand the negative impact of mega-retail-led regeneration on surrounding neighborhoods and to guide its development process and assess its outcome in project evaluation.

One of the important issues raised by megaretail-led regeneration schemes is who gains and who loses by the regeneration process, as public expenditure is necessarily involved in that process. The findings of this paper suggest that landlords in the neighborhood surrounding Westfield London have benefited exclusively from its development. These privatized benefits appear to be unreasonable in that agencies supported by public taxes have been involved in the project and public money has funded the scheme. As such, the efforts of both planning authorities and the academic world are required in order to allow more people to share in the benefits of mega-retail-led regeneration.
I The rate of owner occupied and private rented properties in the borough is $70 \%$, which is higher than the $64 \%$ rate of inner London. Shepherd's Bush Green ward, which is the neighborhood around Westfield London in the spatial boundary of the ward, contains $73 \%$ owner occupied and private rented properties.

2 At the time of its opening, Westfield London was the third largest shopping centre in the UK following Metro Centre and Trafford Centre. Since Westfield Stratford City and Trinity Leeds have opened, Westfield London has become the fifth largest shopping centre in the UK.

3 According to LBHF (2000, 2002), the developer agrees to pay $£$ I.I million for the funding of the Employment and Training Contribution to the Council.

\section{References}

Adlard, H. (200I): The 'Need' for Retail Development. Journal of Planning and Environment Law, 7 (5), pp. г 343-г 362.

Ahlfeldt, G.; Maennig, W. (2009): Arenas, Arena Architecture and the Impact on Location Desirability: The Case of 'Olympic Arenas' in Prenzlauer Berg, Berlin. Urban Studies, 46(7), pp. г 343-г 362.

Barras, R. (2009): Building Cycles: Growth \& Instability. RICS Research. Chicester: Wiley-Blackwell.

Bromley, R.; Thomas, C.; Tallon, A. (2004): Parks Revisited: A Growing Competitive Threat to Traditional Shopping Centres?. Environment and Planning A, 36, pp.647-666.

Colwell, P.; Dehring, C. (2000): The Effect of Group Homes on Neighbourhood Property Values. Land Economics, 76, pp.6 $15-636$.

Crosby, N.; Hughes, C.; Oughton, M. (2006): Messages from the Oracle: Assessing the Impact of Major In-Town Shopping Centres. Reading: University of Reading Business School.

Cummins, S.; Findlay, A.; Petticrew, M.; Sparks, L. (2005): Healthy Cities: The Impact of Food Retail-led Regeneration on Food Access, Choice and Retail Structure. Built Environment, 3 I (4), pp. 288-30 I.

Dehring, C.; Depken, C.; Ward, M. (2007): The Impact of Stadium Announcements on Residential Property Values: Evidence from a Natural Experiment in Dallas-Fort Worth. Contemporary Economic Policy, 25 I (4), pp. 627-638.

Department of the Environment (DOE) (I993): Planning Policy Guidance Note 6: Town Centres and Retail Developments. London: Her Majesty's Stationery Office (HMSO).

Department of the Environment (DOE) (I994): Planning Policy Guidance Note I3: Transport. London: HMSO.

Department of the Environment (DOE) (i996): Planning Policy Guidance Note 6 (Revised): 

HMSO.

Dixon, T. (2005): The Role of Retailing in Urban Regeneration. Local Economy, 20 (2), pp. I 68-1 82.

FLORIDA, R. (2002): The Rise of the Creative Class and How It's Transforming Work, Leisure, Community and Everyday Life. New York: Basic Books.

Griffiths, R. ( 998 ): Making Sameness: Place Marketing and the New Urban Entrepreneurialism. In Oatley, N. (eds.), Cities, Economic Competition, and Urban Policy. London: Paul Chapman.

Guy, C. (г 994): The Retail Development Process: Location, Property and Planning. London: Routledge.

Guy, C. (2002): Is Retail Planning Policy Effective? The Case of Very Large Store Development in the UK. Planning Theory and Practice, 3(3), pp. 3 г $9^{-33 o .}$

Guy, C. (2007): Planning for Retail Development: A Critical View of the British Experience. London: Routledge.

Guy, C. (2008): Retail-led Regeneration: Assessing the Property Outcomes. Journal of Urban Regeneration and Renewal, I (4), pp.378-388.

Guy, C.; Bennison, D. (2002): Planning Policy: Superstore Development and Retailer Competition. International Journal of Retail and Distribution Management, 30 (9), pp. 43 I-434.

Guy, C.; Bennison, D. (2007): Planning Guidance and Large-store Development in the United Kingdom: The Search for 'Flexibility'. Environment and Planning A, 39, pp. 945-964.

Hall, P. (2oo6): Urban Geography, 3rd edition. London: Routledge.

Hackworth, J.; Sмiтh, N. (200I): The Changing State of Gentrification. Tijdschrift voor Economische en Sociale Geografie, 92, pp.464-477.

Harvey, D. (I 989 ): From Managerialism to Entrepreneurialism: The Transformation in Urban Governance in Late Capitalism. Geografiska Annaler, 7 I B, pp. 3-I 7 .

Hoesli, M.; Macgregor, B. (2002): Property Investment. Harlow: Longman.

Jackson, C.; Watkins, C. (20 I i): Planning Policy and Retail Property Investment in the UK. Urban Studies, $42(8)$, pp. I $453-1469$.

KI, C.; Jayantha, W.M. (20 io): The Effects of Urban Redevelopment on Neighbourhood Housing Prices. International Journal of Urban Sciences, I4 (3), pp. 276-294.

Land Registry (20 i ia): Land Registry Public Guide. London: Land Registry.

Land Registry (20 i ib): Land Registry House Price Index July 2 ог . London: Land Registry.

Loftman, P.; Nevin, B. (i994): Prestige Project Developments: Economic Renaissance or Economic Myth: A Case Study of Birmingham. Local Economy, 8 (4), pp.3o7-325.

Loftman, P.; Nevin, B. (I995). Prestige Projects and Urban Regeneration in the r 980 s and r 990 s: A Review of Benefits and Limitations. Planning Practice and Research, Io (3), pp.299-3 г 5 .

Lowe, M. (2000): Britain's Regional Shopping Centres: New Urban Forms?. Urban Studies, $37(2)$, pp. $26 \mathrm{I}-274$.

Lowe, M. (2005a): The Regional Shopping Centre in the Inner City: A Study of Retail-led Urban Regeneration. Urban Studies, 42 (3), pp.449-47o.

Lowe, M. (2005b): Revitalizing inner city retail?: The impact of the West Quay development on Southampton. International Journal of Retail \& Distribution Management, 33(9), pp.658-668.

Office of the Deputy Prime Minister (ODPM) (I998): PATI3, National Strategy for Neighbourhood Renewal, Improving Shopping Access for People Living in Deprived Areas. London: ODPM.

Office of the Deputy Prime Minister and British Retall Consortium (ODPM/BRC) (2003): Research Report 6: Changing Practices-A Good Practice Guide for Businesses Locating in Deprived Areas. London: ODPM.

Office of the Deputy Prime Minister (ODPM) (2005): Planning Policy Statement 6: Planning for Town Centres. London: ODPM.

Oxford Institute of Retail Management (OXIRM) (1987): The New Regional Shopping Centre Phenomenon. Oxford: OXIRM Research Papers.

Phillips, M. (2002): The Production, Symbolization and Socialization of Gentrification: Impressions from Two Berkshire villages. Transactions of the Institute of British Geographers, 27, pp.282-3o8.

Poттs, G. (2007): From 'chains' to partnerships? Supermarkets and regeneration. Journal of Urban Regeneration and Renewal, I (I), pp. 22-36.

Redding, S.; Sturm, D. (2008): The Cost of Remoteness: Evidence from German Division and Re-

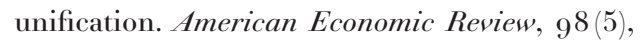
pp. I $766-$ I 797 .

Robertson, J.; Fennelu, J. (2007): The Economic Effects of Regional Shopping Centres. Journal of Retail and Leisure Property, 6 (2), pp. I 49-I 7 o.

Schiller, R. (г986): Retail Decentralization-The Coming of the Third Wave. The Planner, 72,

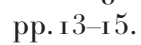

Short, J.; Kiм, Y. (г 999): Globalization and the City. Harlow: Longman.

Sмгтн, N. ( 996 ): The New Urban Frontier: Gentrification and the Revanchist City. London: Routledge.

Sмiтh, N. (2000): Gentrification. In Johnston, R.; Gregory, D.; Pratt. G.; Watts, M. (eds.), the Dictionary of Human Geography. Oxford: Blackwell.

Sмiтh, N. (2002): New Globalism, New Urbanism: Gentrification as Global Urban Strategy. Antipode, $34(3)$.

Sмутн, Н. (г 994): The Role of Flagship Developments in Urban Regeneration. London: Spon press.

Tallon, A. (2008): Mega-retail-led Regeneration. Town and Country Planning, 77.

TAllon, A. (2010): Urban Regeneration in the UK. Abingdon: Routledge.

Tallon, A.; Bromley, R. (2004): Exploring the Attractions of City Centre Living: Evidence and 
Policy Implications in British Cities. Geoforum, $35, \mathrm{pp} \cdot 77^{\mathrm{I}-78} 7$.

The London Borough of Hammersmith and Fulham (LBHF) (2000): Section Io6 Agreement of White City Development in 2ooo. London: LBHF.

The London Borough of Hammersmith and Fulham (LBHF) (2002): Section Io6 Agreement of White City Development in 2002. London: LBHF.

The London Borough of Hammersmith and Fulham (LBHF) (20г1a): White City Opportunity Area Planning Framework: Public Consultation. London: LBHF.

The London Borough of Hammersmith and Fulham (LBHF)(20 I Ib):AbouttheLBHF.Availableathttp:// www.lbhf.gov.uk/Directory/Environment_and_ Planning/Planning/. Accessed 5 September 20 I I.

The London Borough of Hammersmith and Fulham (LBHF) (2012) : Building a Housing Ladder of Opportunity: Housing Strategy Annexes. London: LBHF.

Thomas, C.; Bromley, R. (2002): The changing competitive relationship between small town centres and out-of-town retailing: town revival in South Wales. Urban Studies, 39, pp. $79^{\text {I-8 }} 8$.

Thomas, C.; Bromley, R.; Tallon, A. (2006): New "High Streets" in the Suburbs? The Growing Competitive Impact of Evolving Retail Parks.
International Review of Retail, Distribution and Consumer Research, I 6, pp.43-68.

Transport for London (TFL) (2007): White City Development. London: TFL.

Tu, C. (2005): How Does a New Sports Stadium Affect Housing Values? The Case of FedEx Field. Land Economics, 8 I (3), pp.379-395.

WestField Group (2005): Westfield Group Annual Report 20o5. Sydney: Westfield Group.

Westfield Group (2010): Westfield Group Annual Report 2oo8. Sydney: Westfield Group.

Westfield London (2010): Westfield London Brochure. London: Westfield London.

Woo, M.; Morrow-Jones, H.A. (20II): Main Factors Associated with Homeowners' Intentions to Move. International Journal of Urban Sciences, I 5 (3), pp. I 6 I-I 86.

Wooldridge, J. (2009): Introductory Econometrics: A Modern Approach, 4 th edition. Mason: SouthWestern.

Wrigley, N.; Guy, C.; Lowe, M. (2002): Urban Regeneration, Social Inclusion and Large Store Development: The Seacroft Development in Context. Urban Studies, 39 (I I), pp. 2 I 0 I-2 1 I 4 .

Wrigley, N.; Lowe, M. (2002): Reading retail: $A$ Geographical Perspective of Retailing and Consumption Spaces. London: Arnold.
Jae Kwang Lee The Bartlett School of Planning University College London Faculty of the Built Environment Wates House

22 Gordon Street London, WCIH oQB, UK

j.lee.ıo@ucl.ac.uk 